\title{
PENGEMBANGAN MULTIMEDIA PEMBELAJARAN BAHASA INGGRIS UNTUK SMK
}

\author{
Herman Dwi Surjono, Heni Rita Susila \\ Fakultas Teknik UNY, FKIP Universitas Baturaja \\ hermansurjono@uny.ac.id, henirietta@yahoo.com
}

\begin{abstract}
Abstrak
Penelitian ini bertujuan untuk mengembangkan dan mengevaluasi perangkat lunak multimedia pembelajaran bahasa Inggris untuk siswa Sekolah Menengah Kejuruan. Tahapan penelitian ini meliputi perencanaan, desain dan pengembangan. Tahap perencanaan meliputi penentuan ruang lingkup, identifikasi karakteristik siswa dan pengumpulan bahan ajar. Tahap desain meliputi analisis konsep materi, pembuatan flowcharts dan storyboards. Tahap akhir yakni proses pengembangan meliputi penyiapan komponen multimedia, pembuatan program, dan evaluasi. Evaluasi terdiri atas uji alpha oleh ahli materi dan ahli media, uji beta oleh siswa dan uji sumatif melalui pretes dan postes. Multimedia pembelajaran yang telah dikembangkan ini terdiri atas materi bahasa Inggris dengan topic personality traits, people dan compliments. Menurut ahli materi, media ini termasuk sangat baik dalam aspek pembelajaran dan baik dalam aspek materi. Sedangkan menurut ahli media, media ini termasuk sangat baik. Siswa yang belajar menggunakan media ini mencapai tingkat ketuntasan 70\%, sedangkan yang belajar menggunakan media cetak mencapai ketuntasan $50 \%$.
\end{abstract}

Kata kunci: Multimedia pembelajaran, Bahasa Inggris, Siswa SMK

\section{THE DEVELOPMENT OF MULTIMEDIA LEARNING FOR ENGLISH SUBJECT FOR VOCATIONAL SCHOOL}

\author{
Herman Dwi Surjono, Heni Rita Susila \\ Fakultas Teknik UNY, FKIP Universitas Baturaja \\ hermansurjono@uny.ac.id, henirietta@yahoo.com
}

\begin{abstract}
This study aims to develop and evaluate software of multimedia learning for English subject for vocational students. The development steps are: plan, design and development. The plan includes determining the scope, identifying student, and gathering resources. The design includes analyzing, making flowcharts and storyboards. The development includes creating multimedia components, programming, and evaluating. The evaluation includes alpha testing, beta testing, and summative evaluation. The developed software of multimedia learning for English subjects contains topics of personality traits, people and compliments. According to a subject expert, this software is very good in aspect of learning and good in aspect of material. According to a media expert, the software quality is very good. Students who used this software reached 70\% mastery learning.
\end{abstract}

Keywords: Multimedia Learning, English, Vocational Education 


\section{PENDAHULUAN}

Meningkatnya daya saing dan keunggulan kompetitif dari semua sektor, menuntut manusia untuk mempunyai kemampuan yang semakin berkualitas baik dalam bidang Sumber Daya Manusia (SDM), ilmu maupun teknologi, agar manusia tetap mampu bertahan dalam kehidupannya. Hanya SDM dengan kualitas tinggi yang akan menang dalam ketatnya persaingan hidup. Salah satu sarana yang harus dikuasai dalam menghadapi era globalisasi tersebut adalah kemampuan berkomunikasi dengan bahasa Inggris, sehingga bahasa Inggris sangat ditekankan penguasaannya di Indonesia.

Bahasa Inggris merupakan salah satu mata pelajaran yang masuk dalam kurikulum di SMK, akan tetapi proses pembelajaran bahasa Inggris masih belum bisa mencapai hasil seperti yang diharapkan. Hal ini terbukti dengan masih banyaknya siswa yang tetap belum mampu berkomunikasi menggunakan bahasa Inggris walaupun mereka sudah mempelajarinya sejak memasuki bangku Sekolah Dasar (SD) hingga Sekolah Menengah Atas ataupun yang sederajat. Kondisi pembelajaran ini mengharuskan guru aktif dan kreatif menyiasati, mencari dan memilih strategi pembelajaran yang paling tepat untuk mencapai tujuan pembelajaran yang terkait dengan proses dan hasil pembelajaran. Pelaksanaan pembelajaran di dalam kelas merupakan salah satu tugas utama guru yang dapat diartikan sebagai kegiatan yang ditujukan untuk membelajarkan siswa. Dalam proses pembelajaran masih sering ditemui adanya kecenderungan siswa lebih pasif sehingga mereka lebih banyak menunggu sajian guru daripada mencari dan menemukan sendiri pengetahuan, keterampilan atau sikap yang mereka butuhkan.

Salah satu aspek yang jelas dan tampak dalam pembelajaran adalah dipergunakannya prinsip-prinsip teknologi dalam masalah belajar dengan mengembangkan teknologi sebagai sumber belajar. Kegiatan ini merupakan suatu langkah yang harus dilakukan oleh setiap pengajar dalam proses pembelajaran. SMK (Sekolah Menengah Kejuruan) merupakan lembaga atau institusi pendidikan menengah yang mempersiapkan siswa untuk bekerja dalam bidang keahlian tertentu.
Pengembangan multimedia pembelajaran sangat diperlukan di lingkup Sekolah Menengah Kejuruan (SMK), karena banyak kendala yang dihadapi oleh guru mata pelajaran adaptif, normatif maupun produktif dalam menyampaikan materi pelajaran kepada siswa. Kekurangminatan siswa pada pelajaran adaptif khususnya pelajaran bahasa Inggris karena mereka beranggapan bahwa pelajaran bahasa Inggris memiliki tingkat kesulitan dan pemahaman yang tinggi, padahal bahasa Inggris merupakan keterampilan yang harus dikuasai untuk menghadapi kecepatan perubahan dan kemajuan Iptek yang diaplikasikan di industri menuntut SDM yang berkualitas termasuk dalam kemampuannya berbahasa Inggris. Kemampuan berbahasa Inggris harus dikuasai oleh seluruh siswa, dengan adanya keadaan yang demikian, maka diperlukan kerja keras guru mata pelajaran bahasa Inggris untuk dapat meningkatkan hasil belajar bahasa Inggris seperti yang diharapkan. Pengembangan multimedia pembelajaran dalam bentuk CD interaktif diharapkan menjadi solusi yang tepat untuk mengatasi masalah-masalah pembelajaran bahasa Inggris yang ada sekarang.

Turban dkk (Suyanto, 2005: 21) mengemukakan bahwa multimedia adalah kombinasi dari paling sedikit dua media input atau output. Media ini dapat berupa audio (suara, musik), animasi, video, teks, grafik, dan gambar. Azhar Arsyad (2009:170) menyatakan multimedia secara sederhana didefinisikan lebih dari satu media, media ini bisa berupa kombinasi antara teks, grafik, animasi, suara dan video. Blackwell (1997: 1) dalam multimedia application in education menyatakan bahwa multimedia adalah kombinasi dari teks, grafik, seni, suara, animasi dan video dengan link atau alat yang memungkinkan bagi guru ataupun siswa untuk mengendalikan, berinteraksi dan berkomunikasi dengan komputer. Ketika user bisa mengontrol apa dan kapan saja unsur-unsur yang ada dalam media tersebut maka proses ini disebut multimedia interaktif, jadi dengan menggunakan multimedia, siswa tidak hanya bisa melihat dan mendengar tetapi juga bisa juga mengatur perintah-perintah didalamnya secara stimulan. Dari pendapat Blackwell dapat dikatakan bahwa multimedia merupakan suatu kombinasi data yang memuat jenis dan media untuk menyampaikan pesan menjadi lebih kominukatif dan berkesan. 
Pembelajaran pada hakekatnya merupakan upaya membelajarkan siswa, sedangkan perancangan pembelajaran merupakan penataan upaya tersebut agar muncul perilaku belajar. Yusufhadi Miarso (2004: 457) memberikan pendapatmya bahwa istilah pembelajaran digunakan untuk menunjukkan usaha pendidikan yang dilaksanakan secara sengaja, dengan tujuan di tetapkan terlebih dahulu sebelum proses dilaksanakan, serta pelaksanaannya terkendali. Pengertian belajar menurut Teori Behavioristik adalah perubahan tingkah laku sebagai akibat dari adanya interaksi antara stimulus dan respon. Seseorang dianggap telah belajar bila ia mampu menunjukkan perubahan tingkah laku. Faktorfaktor yang penting dalam teori behavioristik adalah stimulus, respon dan reinforcement. Selain teori behavioristik, belajar bahasa Inggris juga didasari pada teori belajar kognitif karena dalam teori belajar kognitif siswa haruslah aktif mengikuti pelajaran. Model belajar kognitif mengatakan bahwa tingkah laku seseorang ditentukan oleh persepsi serta pemahamannya tentang situasi yang berhubungan dengan tujuan belajarnya (Asri Budiningsih, 2005: 34). karena sebenarnya siswa sudah memiliki pengetahuan di dalam dirinya dan siswa sendiri yang membangun pengetahuan tambahan dengan caranya sendiri.

Produk yang akan dikembangkan dalam penelitian ini adalah multimedia interaktif bukan multimedia pembelajaran berbasis komputer yang linier. Pada multimedia linier siswa harus mengikuti urutan materi seperti yang disajikan. Produk multimedia interaktif ini memberi kesempatan pada siswa untuk memilih materi sesuai dengan tahap-tahap perkembangan belajar mereka, sesuai dengan tingkat kemampuan siswa, kebutuhan dan kecepatan dalam belajarnya, sebagaimana yang dinyatakan oleh Piaget dalam teori perkembangan kognitifnya.

Pengembangan multimedia pembelajaran ini juga menggunakan teori belajar sosial sebagai landasan dalam pengembangannya. Istilah yang terkenal dalam teori belajar sosial adalah modeling (peniruan). Bandura dalam (Eggen P dan Kauchak D, 2004: 216) menyatakan bahwa prinsip dasar teori ini adalah bahwa individu belajar melalui peniruan (imitation) dan penyajian contoh perilaku (modeling). Dengan dilandasi teori di atas, agar pronunciation siswa bisa diucapkan dengan benar sesuai dengan pengucapan penutur bahasa asli (native speaker), konsekuensinya sebuah media pembelajaran harus menampilkan model dan contoh-contoh pengucapan dari setiap kosakata baru yang ada dalam materi. Model yang ditampilkan berupa video conversation yang diperankan oleh native speaker.

Tujuan dari mata pelajaran bahasa Inggris di SMK adalah agar peserta didik memiliki kemampuan untuk menguasai pengetahuan dan keterampilan dasar untuk mendukung kompetensi program keahlian dan menerapkan penguasaan kemampuan dan keterampilan berbahasa Inggris untuk berkomunikasi baik lisan maupun tertulis pada level intermediate. Oleh karena itu, pendekatan yang diterapkan dalam menyajikan pembelajaran bahasa Inggris adalah memberikan model-model dan contoh-contoh real dalam pembelajaran bahasa Inggris berupa percakapan yang diucapkan oleh native speaker, video dengan menampilkan native speaker sebagai model, dan contoh-contoh pronunciation untuk setiap kosakata baru.

Pertanyaan yang harus dijawab dalam penelitian ini adalah:

1. Bagaimana mengembangkan software multimedia pembelajaran bahasa Inggris untuk siswa SMK?

2. Bagaimana kelayakan software pembelajaran tersebut?

3. Bagaimana prestasi siswa yang telah menggunakannya dalam proses belajar mengajar di kelas?

\section{MEDOTE}

Penelitian ini merupakan penelitian pengembangan atau dikenal dengan istilah R\&D (Research and Development), yang bertujuan untuk mengembangkan multimedia pembelajaran berbasis komputer berupa media pembelajaran interaktif, yang berorientasi pada produk. Model pengembangan yang digunakan oleh peneliti adalah model pengembangan dan desain multimedia yang dikembangkan oleh Stephen M. Alessi dan Stanley R. Trollip (2001: 401).

Prosedur penelitian pengembangan ini memiliki serangkaian prosedur sebagai berikut: 


\section{Perencanaan}

1. Mendefinisikan bidang/ruang lingkup yang diambil dari silabus dan RPP guru mata pelajaran bahasa Inggris.

2. Mengidentifikasi karakteristik siswa dari hasil pra survei.

3. Membuat dokumen perencanaan, mengenai materi, hal-hal yang diperlukan dalam membuat produk, dll.

4. Menentukan dan mengumpulkan sumbersumber untuk mata pelajaran bahasa Inggris, misalnya: dari buku, internet, sekolah, dll.

5. Melakukan brainstorming yaitu melakukan diskusi dengan guru mata pelajaran bahasa Inggris, dan teman sejawat.

\section{Desain}

1. Melakukan analisis konsep dan tugas yang berkaitan dengan materi.

2. Membuat flowcharts dan storyboards.

\section{Pengembangan}

1. Menyiapkan teks (tentang materi untuk keselurahan dalam pembuatan produk CD interaktif)

2. Menggabungkan bagian-bagian dan memadukan berbagai bahan yang telah terkumpul.
3. Menyiapkan materi-materi pendukung.

4. Membuat program.

5. Melakukan uji alpha, yaitu memvalidasi produk yang dilakukan oleh ahli media dan ahli materi (evaluasi formatif).

6. Membuat revisi yang pertama terhadap produk yang telah dibuat.

7. Melakukan uji beta, yaitu menguji produk ke 6 orang siswa untuk mengetahui tanggapan siswa terhadap produk yang dibuat (evaluasi formatif).

8. Melakukan revisi akhir yaitu membuat produk final software pembelajaran bahasa Inggris dalam bentuk $C D$ pembelajaran interaktif.

9. Melakukan evaluasi sumatif dengan mengadakan pretest dan posttest pada kelas dengan pembelajaran menggunakan media cetak dan kelas yang menggunakan media berbasis komputer dan melihat rerata hasil belajar setiap kelas tersebut.

Secara keseluruhan pada tahap pengembangan ini dilakukan ongoing evaluation yaitu evaluasi terus menerus dari awal hingga akhir pengembangan. Tahap ini dilakukan dengan uji alpha dan uji beta, serta melakukan revisi terhadap produk secara keseluruhan. Proses selengkapnya pengembangan multimedia menurut Alessi \& Trollip seperti yang disajikan pada Gambar 1.

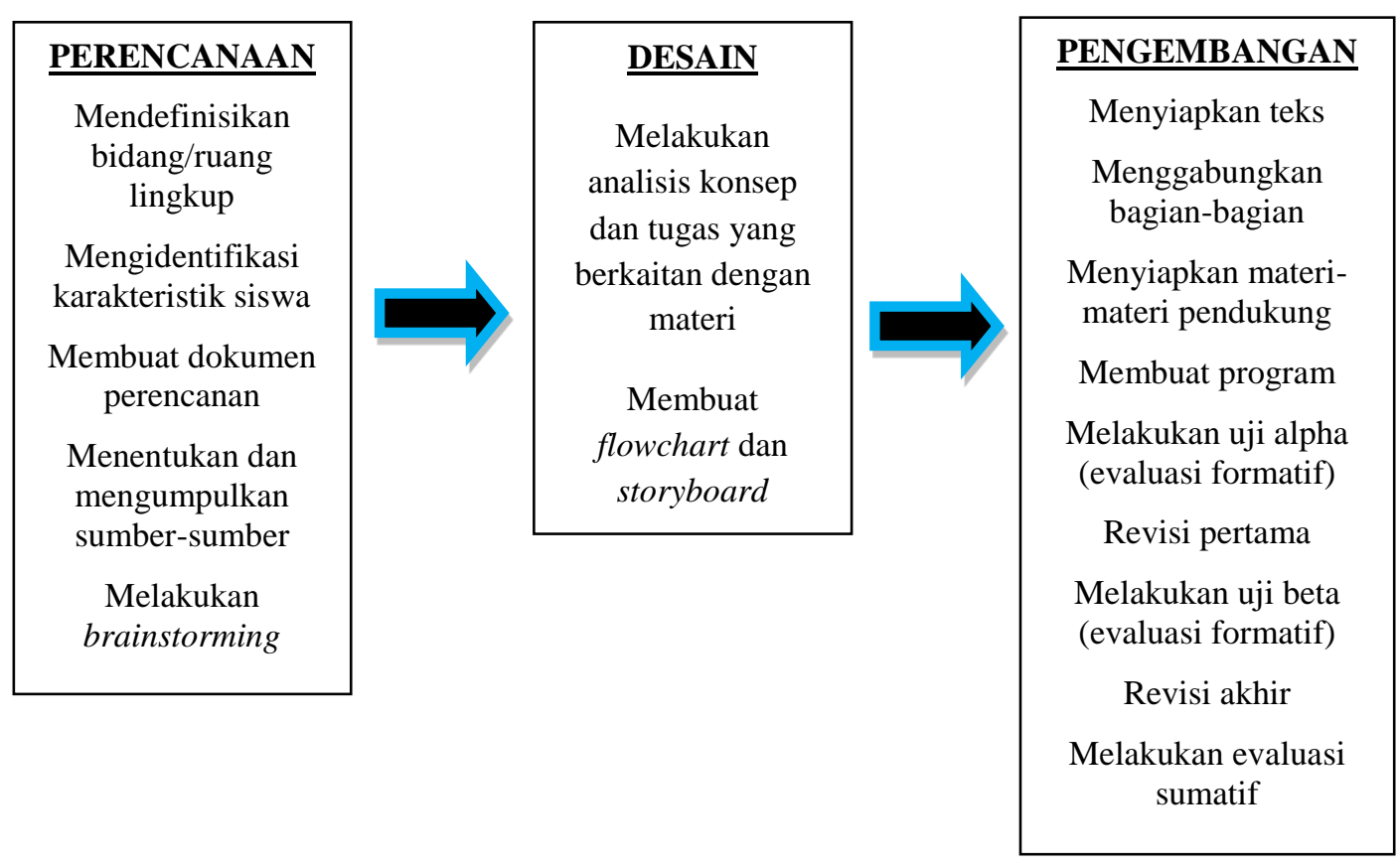

Gambar 1. Proses Pengembangan Multimedia Pembelajaran 


\section{HASIL PENELITIAN}

Hasil penelitian ini berupa software multimedia pembelajaran mata pelajaran Bahasa Inggris dengan topik personality traits, describing people dan compliments untuk siswa kelas $\mathrm{X}$ di SMK. Tampilan halaman kompetensi software multimedia pembelajaran ini dapat dilihat pada gambar 2 . Sedangkan contoh tampilan salah satu halaman materi disajikan pada gambar di bawah ini.

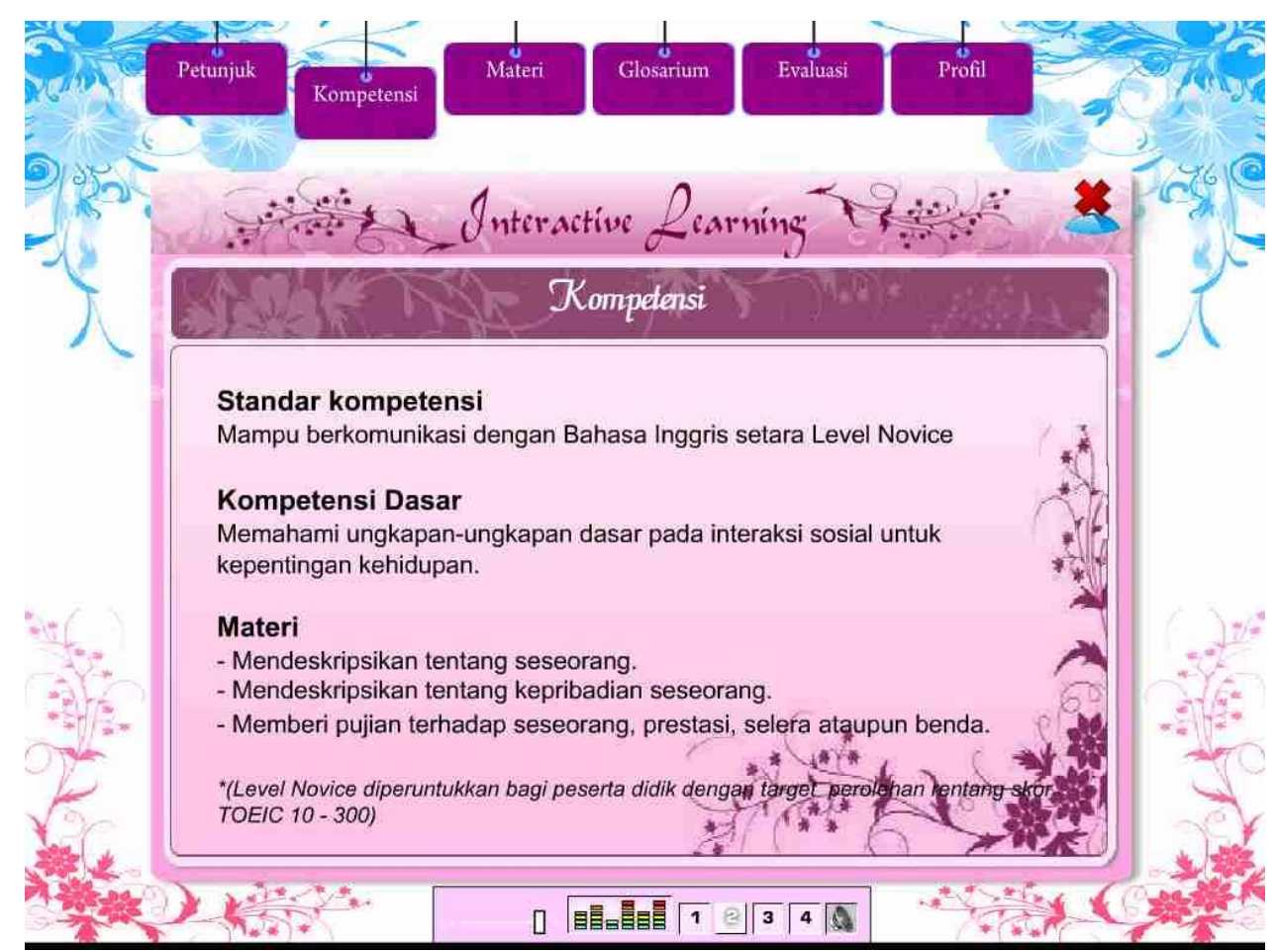

Gambar 2. Grafik Peningkatan Minat dalam Proses Pembelajaran

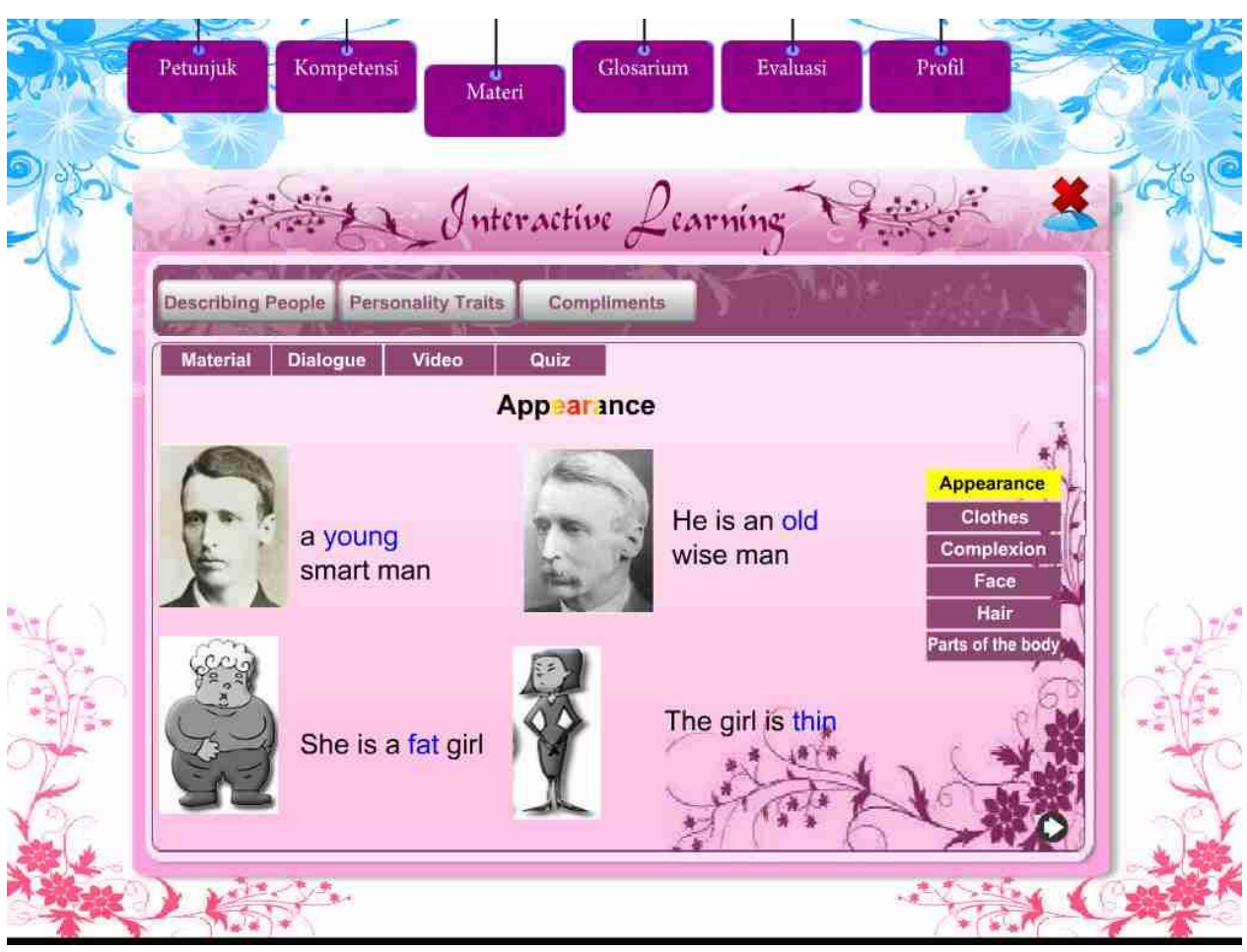

Gambar 3. Tampilan halaman kompetensi software multimedia pembelajaran 
Multimedia pembelajaran ini mencakup enam menu utama yaitu menu petunjuk, kompetensi, materi, latihan, glossarium dan profil. Menu petunjuk berisi petunjuk singkat tentang penggunaan media yang disertai dengan gambar untuk mempermudah user memahami cara menggunakan media. Menu kompetensi merangkum standar kompetensi dan kompetensi dasar yang akan dicapai setelah siswa belajar menggunakan media ini, menu materi berisi tentang materi yang mencakup tiga topik yaitu personality traits, describing people dan compliments, dengan rincian 28 frame untuk topik describing people, 16 frame untuk topik personality traits dan 13 frame untuk compliments termasuk didalamnya video dan quiz untuk membantu user menguji pemahamannya terhadap materi yang dipelajari. Menu latihan berisi soal-soal yang terdiri dari 30 soal masing-masing 10 soal untuk setiap topik, setelah selesai mengerjakan user bisa mengetahui perolehan skor dan user bisa mencoba lagi jika merasa belum puas. Software utama yang digunakan untuk pembuatan multimedia ini adalah macromedia flash 8 . Untuk menjalankan multimedia ini user membutuhkan komputer dengan qualifikasi minimal pentium 3, ruang hardsik $100 \mathrm{MB}$, RAM 128, memiliki CD/DVD ROM.

Dalam uji coba produk diperoleh tiga jenis data, yaitu data uji alpha untuk uji kelayakan terbatas yang dilakukan oleh 1 orang ahli materi bahasa Inggris dan 1 orang ahli media, data uji beta yang dilakukan oleh 6 orang siswa dengan tingkat kemampuan tinggi 2 orang, sedang 2 orang dan rendah 2 orang, serta data validasi uji coba produk yang dilakukan pada kelas yang menggunakan pembelajaran dengan menggunakan media berbasis komputer siswa kelas $\mathrm{X}$ di SMK YPE Kroya Jawa Tengah.

Data yang diperoleh dari hasil validasi oleh ahli materi dikonversi ke dalam skala 5. Berdasarkan hasil olahan data, ratarata skor penilaian oleh ahli materi pada aspek pembelajaran adalah 3,90 dari 10 item yang divalidasi dan masuk dalam kategori baik. Sedangkan pada aspek materi adalah 4,54 dari 13 item yang divalidasi dan masuk dalam kategori sangat baik.

Informasi mengenai penilaian ahli materi tersebut disajikan pada Tabel 1 .

Tabel 1. Distribusi Frekuensi Penilaian oleh Ahli Materi

\begin{tabular}{ccccc}
\hline \multirow{2}{*}{ Kriteria } & \multicolumn{2}{c}{ Aspek Pembelajaran } & \multicolumn{2}{c}{ Aspek Materi } \\
\cline { 2 - 5 } & Frekuensi & Persentase & Frekuensi & Persentase \\
\hline Sangat baik & 1 & $10 \%$ & 7 & $53 \%$ \\
Baik & 7 & $70 \%$ & 6 & $47 \%$ \\
Cukup & 2 & $20 \%$ & 0 & $0 \%$ \\
Tidak baik & 0 & $0 \%$ & 0 & $0 \%$ \\
Sangat tidak baik & 0 & $0 \%$ & 0 & $0 \%$ \\
Jumlah & 10 & 100 & 13 & $100 \%$ \\
\hline
\end{tabular}

Data yang diperoleh dari hasil validasi oleh ahli media dikonversi ke dalam skala 5 . Berdasarkan hasil olahan data yang diperoleh dari 20 item yang di validasi oleh ahli media, rerata yang diperoleh adalah 4,85 , sehingga kriteria penilaian pada aspek media termasuk dalam kriteria sangat baik. Informasi mengenai penilaian ahli materi tersebut disajikan pada Tabel 2.

Tabel 2. Distribusi Frekuensi Penilaian oleh Ahli Media

\begin{tabular}{ccc}
\hline Kriteria & Frekuensi & Persentase \\
\hline Sangat baik & 17 & $85 \%$ \\
Baik & 3 & $15 \%$ \\
Cukup & 0 & $0 \%$ \\
Tidak baik & 0 & $0 \%$ \\
Sangat tidak baik & 0 & $0 \%$ \\
Jumlah & 20 & 100 \\
\hline
\end{tabular}


Dari 13 item yang divalidasi dengan uji beta, maka tanggapan dari siswa termasuk kriteria baik, dengan rerata 3,59. Tanggapan yang berupa saran dan komentar dari siswa adalah dengan memberikan tambahan musik dan latihan pada materi describing people.

Berdasarkan hasil angket yang telah dibagikan kepada 20 siswa yang mengikuti pembelajaran menggunakan media komputer, dari 13 item yang yang divalidasi diperoleh rerata skor 4,36 maka tanggapan siswa termasuk dalam kategori sangat baik. Saran yang diberikan oleh siswa yaitu bahwa glossary perlu ditambah kosakatanya agar lebih mempermudah siswa dalam pemahaman materi.

\section{PEMBAHASAN}

Hasil observasi terhadap proses pembelajaran bahasa Inggris di SMK YPE Kroya menunjukkan bahwa siswa kurang antusias dalam mengikuti proses pembelajaran bahasa Inggris karena strategi pembelajaran yang diterapkan cenderung menggunakan pendekatan ekspositori, dan masih sering terpaku pada teacher centered learning atau hanya guru yang menjadi sumber belajar siswa. Setelah memperoleh informasi tentang ruang lingkup batasan dan karakteristik peserta didik, pengembang membuat dokumen perencanaan mengenai materi dan hal-hal lain yang diperlukan untuk membuat produk. Dari silabus mata pelajaran bahasa Inggris dan hasil belajar siswa, ditemukan bahwa siswa masih menemui kesulitan-kesulitan khususnya pada kompetensi mampu memahami ungkapan-ungkapan sederhana untuk interaksi sosial dalam kehidupan, kemudian pengembang menentukan materi describing people, personality traits dan compliments sebagai materi yang akan disajikan dalam produk media pembelajaran ini.

Analisis dalam uji alpha terdiri dari analisis validasi ahli media dan analisis validasi ahli materi dengan hasil sebagai berikut: 10 butir indikator pada aspek pembelajaran mendapatkan skor rata-rata sebesar 3,87 yang termasuk dalam kategoriartinya dalam kategori "Baik". Ada satu item indikator yang mendapatkan kategori sangat baik yaitu kejelasan petunjuk belajar. Sedangkan hasil analisis dari ahli media, rerata skor yang diperoleh dari 20 item yang di validasi adalah
4,85. Sehingga kriteria penilaian pada aspek media termasuk dalam kriteria sangat baik, dari hasil Analisis uji beta diperoleh skor rerata 3,59 maka secara keseluruhan hasil penilaian dari 6 orang siswa dalam uji beta produk media pembelajaran bahasa Inggris untuk SMK ini masuk pada dalam kategori sangat baik. Hasil uji coba produk diberikan kepada 20 siswa dengan kempuan rendah, sedang dan tinggi, dengan 13 item yang yang divalidasi diperoleh rerata skor 4,36, tanggapan siswa ini termasuk dalam kategori sangat baik, dengan demikian secara keseluruhan dikatakan bahwa multimedia pembelajaran berbasis komputer yang dikembangkan termasuk dalam kriteria sangat baik.

Untuk evaluasi sumatif dilakukan implementasi software multimedia pembelajaran ini kepada 20 siswa kelas $X$ di SMK YPE Kroya tahun pelajaran 2008/2009 dalam mata pelajaran Bahasa Inggris. Sebagai pembanding dilakukan juga pembelajaran untuk materi yang sama namun menggunakan media cetak kepada 20 siswa yang lain. Sebelum dilakukan pembelajaran, siswa diberikan pretest dan sesudahnya diberikan post-test. Tingkat keberhasilan dilihat dari jumlah siswa yang mencapai KKM (Kriteria Ketuntasan Minimal). Pada kelas yang menggunakan software pembelajaran, persentase siswa yang mencapai KKM adalah $10 \%$ pada saat pretest, dan $70 \%$ pada saat posttest. Sedangkan pada kelas yang menggunakan media cetak adalah $10 \%$ untuk pretest, dan $50 \%$ untuk posttest.

\section{KESIMPULAN}

Berdasarkan hasil analisis dan pembahasan dapat disimpulkan sebagai berikut:

1. Multimedia pembelajaran bahasa Inggris untukSMK dikembangkan dengan menggunakan program komputer Macromedia Flash 8. Pengembangan tersebut melalui tahap perencanaan, tahapan desain, dan tahap pengembangan yang didalamnya termasuk evaluasi formatif dan evaluasi sumatif. Multimedia pem-belajaran yang telah dikembangkan ini terdiri atas materi bahasa Inggris dengan topic personality traits, people dan compliments.

2. Setelah dilakukan serangkaian uji coba dan revisi oleh ahli media dan ahli materi, ditinjau dari aspek materi termasuk dalam kategori baik dan dari 
aspek pembelajaran termasuk dalam kategori sangat baik. Dari aspek media, kualitas media pembelajaran bahasa Inggris untuk SMK dinyatakan sangat baik. Tanggapan siswa terhadap media pembelajaran ini termasuk dalam kategori baik.

3. Pengunaan media pembelajaaran $\mathrm{CD}$ interaktif bahasa Inggris dinilai dapat meningkatkan hasil belajar siswa baik dari aspek afektif maupun aspek kognitif. Aspek afektif dilihat berdasarkan hasil observasi selama proses uji coba, yaitu siswa terlihat senang, termotivasi, antusias dan semangat selama mengikuti pembelajaran dengan media komputer. Respon siswa selama proses pembelajaran tersebut mempengaruhi hasil belajar siswa dari aspek kognitif yaitu meningkatnya hasil belajar, yang terbukti dengan meningkatnya jumlah siswa yang mencapai KKM (dari 10\% saat pre-test menjadi $70 \%$ saat post-test).

\section{DAFTAR PUSTAKA}

AECT. (1977). The definition of educational technology. Washington, D.C. Association for Education Communication and Technology.

Blackwell, John. (1997). Multimedia application in education. Diambil pada tanggal 26 mei 2009, dari http://web.viu.ca/seeds/mm/index.html.

Agnew, P.W., Kellerman, .A.S., \& Meyer, J.M. (1996). Multimedia in the classroom. Massachutsetts: Allyn \& Bacon.

Alessi, S.M. \& Trollip, S.R. (2001). Multimedia for learning : methods and development $\left(3^{\text {th }}\right.$ ed.). Massachusetts : Ally \& Bacon A Pearson Education Company

Asri Budiningsih. (2005). Belajar dan pembelajaran. Yogyakarta: FIP UNY.

Azhar Arsyad. (2007). Media pembelajaran. Jakarta: PT Raja Grafindo Persada.
Brown, H.D. (2001). Teaching by principles an interactive approach to language pedagogy. New York: Longman.

Bormann, E.G. \& Borman, N.G. (1981). Speech communication. New York: Harper \& Row.

Eggen, P \& Kauchak, D. (2004). Educational psychology: Windows on classroom $\left(6^{\text {th }}\right.$ edition). New Jersey: Prantice Hill Inc

Kurikulum. (2003). Kurikulum 2004 standar kompetensi Sekolah Menengah Atas dan Madrasah Aliyah: pedomam khusus mata pelajaran Bahasa Inggris. Jakarta: Dharma Bhakti.

Lee, W.W., \& Owens, D.L. (2004). Multimedia based instructional design $\left(2^{\text {th }}\right.$ ed.). San Francisco: Pfeiffer.

Liu,Yuliang. (2005). Effects of online instruction vs traditional instruction on student's learning. International journal of instructional technology and distance learning. Diambil tanggal 3 May 2009, dari http://itdl.org/Journal/ Mar_05/article06.htm.

Seels, B. B., \& Richey, R. C. (1994). Instructional technology; The definition and domain of the field. Washington DC: Association for Education Communication and Technology.

Sukardjo. (2008). Desain pembelajaran: evaluasi pembelajaran. Hand-out perkuliahan : PPs Universitas Negeri Yogyakarta

Sugiyono. (2008). Metode penelitian pendidikan pendekatan kuatitatif, kualitatif, dan R \& D. Bandung: Alfabeta

Suyanto, M. (2003). Multimedia: Alat untuk meningkatkan keunggulan bersaing. Yogyakarta: Andi Offset.

Yusufhadi Miarso. (2005). Menyemai benih teknologi pendidikan. Jakarta: Kencana. 